\title{
Pitiose mamária secundária à lesão cutânea em potra Quarto de Milha: relato de caso
}

Lucas Ferreira Mendonçç ${ }^{[]^{*}}$, Paulo Aléscio Canola ${ }^{[a]}$, Júlia Ribeiro Garcia Carvalho ${ }^{[a]}$, Marina Lansarini antonioli[a], Caio Carvalho Bustamante ${ }^{[a]}$, Paula Luzia Formigoni Bergamasco ${ }^{[a]}$, Vanessa Barroco de Paula ${ }^{[a]}$, Talissa Camargo Mantovani de Bonis ${ }^{[a]}$ Dábia Silva Teixeira ${ }^{[b]}$

[a] Universidade Estadual Paulista (UNESP), Jaboticabal, SP, Brasil

[b] Universidade Federal de Lavras (UFLA), Lavras, MG, Brasil

*Autor correspondente

e-mail: lucasfm.mv@hotmail.com

\section{Resumo}

A pitiose cutânea é uma doença infecciosa piogranulomatosa causada pelo oomiceto aquático Pythium insidiosum. 0 acúmulo de água em banhados e lagoas, além da presença de vegetação aquática e temperatura ambiente elevada $\left(30\right.$ a $\left.40^{\circ} \mathrm{C}\right)$, são fatores imperativos para a formação dos zoósporos infectantes, os quais, posteriormente, sofrem quimiotaxia para os tecidos danificados do hospedeiro. 0 quadro é caracterizado pela presença de lesões ulcerativas, com extensão variada, bordas irregulares e drenagem abundante de secreção serossanguinolenta, associada a tratos fistulosos preenchidos por material branco-amarelado irregular e firme denominado kunkers. 0 diagnóstico pode ser baseado na caracterização clínica das lesões cutâneas associado ao resultado histopatológico. Entretanto, é necessária a confirmação por meio de exames complementares, como a imunohistoquímica ou reação em cadeia da polimerase (PCR). 0 tratamento ainda é um grande desafio e sua eficácia depende de fatores como tamanho e localização da lesão, evolução, imunidade do paciente e terapia instituída. Usualmente, combina-se excisão cirúrgica com imunoterapia ou administração sistêmica, intralesional e tópica de drogas antifúngicas, juntamente com cauterização da ferida. Foi admitido no Hospital Veterinário da FCAV/Unesp, câmpus de Jaboticabal um equino, fêmea, da raça Quarto de Milha, de 1 ano e 6 meses, pesando $170 \mathrm{~kg}$, apresentando feridas na região medial dos membros pélvicos, em altura de tíbia e fíbula. Segundo o proprietário, as feridas haviam sido inicialmente observadas há aproximadamente três semanas, com rápida evolução e prurido intenso. Ainda segundo o mesmo, a paciente permanecia em pastagem, a qual apresentava várias áreas de alagamento. No exame físico foi observada a presença de secreção serossanguinolenta abundante e presença de kunkers nas feridas. Pelo aspecto macroscópico da lesão, suspeitou-se de pitiose cutânea. Por meio de exames complementares, identificou-se Babesia equi e eritropenia acentuada $(2,76 \times 106 \mathrm{he} / \mu \mathrm{L})$, possivelmente 
causada pela presença do hemoparasita, e drenagem abundante de secreção serosanguinolenta pelas feridas. A paciente foi submetida ao procedimento de exérese cirúrgica do tecido granulomatoso, seguido de cauterização e aplicação tópica de anfotericina B com DMSO e bandagem compressiva. No entanto, dada à extensão da lesão, houve recidiva da afecção e aventou-se nova tentativa de extirpação cirúrgica do tecido granulomatoso. 0 tratamento pós-operatório foi feito com terapia antimicrobiana de amplo espectro, anti-inflamatório não esteroidal e troca da bandagem a cada dois dias, com aplicação tópica da solução supracitada. Entre uma intervenção cirúrgica e outra, notou-se aumento de volume na região inguinal direita. Com o auxílio do aparelho de ultrassonografia, observou-se presença de líquido inflamatório na glândula mamária direita e pontos hiperecoicos, sugestivos de presença kunkers no tecido mamário. Após alguns dias do último procedimento cirúrgico, o animal veio a óbito. A paciente foi encaminhada à necropsia, onde foi confirmada a infiltração no tecido mamário e linfonodo inguinal pelo Pythium insidiosum e presença de kunkers. Conforme citado anteriormente, a pitiose cutânea é comum em equinos habitando áreas alagadas. Lesões gástricas e pulmonares já foram relatadas em casos graves. No entanto, na paciente em questão, não foram encontradas lesões semelhantes; porém, com os achados ultrassonográficos e, posteriormente, com a necropsia, observou-se envolvimento da glândula mamária e linfonodos inguinais. A disseminação do pseudofungo para estes tecidos, nesse caso, possivelmente ocorreu por via linfática. Metástase é definida como a disseminação, pelo sangue ou via linfática, de organismos patológicos, além do foco primário de uma lesão. Neste sentido, pode-se inferir que houve metástase (linfática) mamária da lesão cutânea primária.

Palavras-chave: Anfotericina B. Equino. Kunkers. 